\title{
Crop-weather based relation and severity prediction of aerial blight incited by Rhizoctonia solani Kuhn in soybean
}

\author{
PAWAN K. AMRATE, M. K. SHRIVASTAVA and D.K. PANCHESHWAR \\ AICRP on Soybean, Department of Plant Breeding and Genetics, Jawaharlal Nehru Krishi Vishwa Vidyalaya, \\ Jabalpur - 482004 \\ Corresponding author: pawanamrate@gmail.com
}

\begin{abstract}
Crop-weather based relation and other aspects of aerial blight incited by Rhizoctoniasolani Kuhn were investigated on two mega varieties (JS 335 and JS 97-52, now susceptible) under central Indian conditions during 2017, 2018 and 2019. It was found that aerial severity and sclerotial formation on affected leaves were varied significantly in all three season, and progress of disease was rapid between 63-84 days old crop \{full pod (R4) to maturity initiation (R7) stage\}.Increasing crop age was also significantly positively correlated with increasing severity $\left(0.732^{*}\right)$ and sclerotial formation $\left(0.981^{* *}\right)$. Mean relative humidity and maximum temperature of current as well as previous week were found to be positively and negatively correlated with increasing severity of aerial blight, respectively. A regression based model with three explanatory variables (Mean $\mathrm{RH}$, Rainfall and Minimum temperature) of current week was found to be most significant in prediction of disease severity $\left(R^{2}=0.946\right)$ of aerial blight. Whereas previous week weather variables i.e. rainy days and rainfall were also accounted 71.7 per cent variability $\left(R^{2}=0.717\right)$ in disease severity. Overall, weekly average maximum temp $\left(27\right.$ to $\left.30^{\circ} \mathrm{C}\right)$ and mean $\mathrm{RH}$ ( 80 to 90 per cent) in current week coupled with more rainfall and rainy days in previous week were found to be most conducive field condition for rapid progress of aerial blight disease in soybean.
\end{abstract}

Key word: Weather parameters, aerial blight, sclerotia, soybean, correlation, prediction model

Soybean (Glycine max L. Merrill) also known as "miracle legume" is one of the most important crop grown throughout the world for its high value of nutrition ( $40 \%$ protein and $20 \%$ oil). During 2018-19, India ranked fifth largest producer (10.93 million ton in 10.83 million ha area) of soybean after USA, Brazil, Argentina and China (Anonymous, 2020). Madhya Pradesh is a prominent state accounts $>50 \%$ of area and production of soybean in India. Soybean is a weather sensitive crop and variables i.e. increasing/fluctuating average temperature and cumulative rainfall reduces yield directly (Mohanty et al., 2017) as well as also influence insect pest population (Prasad et al., 2013). The crop is also attacked by several plant pathogenic agents and diseases (Sinclair, 1984).

Soybean Aerial or foliar blight caused by Rhizoctoniasolani Kuhn (teleomorph: Thanatephorus cucumeris (Frank) Donk) is one of the most destructive disease of soybean that causes considerable seed yield loss in many countries including India (Naito et al., 1995; Wan et al., 2005; Williamson et al., 2006; Wratheret al., 2010). It can be easily diagnosed by presence of light to dark brown spots, superficial web like mycelium and sclerotia on affected tissue (Verma and Thapliyal, 1976, Sinclair, 1984). Rhizoctonia survives in the soil in the form of sclerotia and remains viable for a longer period under adverse condition (Sinclair, 1984; Manian and Manibhushan, 1990). Initially inoculum infects seedling, stems and close canopy thereafter fungus progressed rapidly between plant to plant and severity of aerial blight fluctuates with prevailing rainfall and Relative humidity (Yang et al., 1990 and Joye et al., 1990).

In India, aerial blight usually affect soybean crop in Uttarakhand, Madhya Pradesh and Chhatishgarh (Wratheret al., 2010; Mathpal and Singh, 2017). Disease is difficult to manage by using host resistance as most of mega varieties and germplasm of soybean are moderately susceptible to it (Amrate et al., 2018; 2020). Information on crop-weather and disease relation helps in deriving other management strategies of disease. Therefore, the present investigations were undertaken to reveal crop weather relationship and other aspects of aerial blight of soybean that might be useful in minimizing severity by formulating need based effective strategies for central India as well as other part of the country. 


\section{MATERIALS AND METHODS}

\section{Experimental site and details}

A field trial was carried out, to reveal epidemiology of Aerial blight of soybean, at experimental site of All India Coordinated Research Project (AICRP) on soybean in Jawaharlal Nehru Krishi Vishwa Vidyalaya, Jabalpur (Latitude: $23^{\circ} 14 \mathrm{~N}$, Longitude: $79^{\circ} 56 \mathrm{E}$, Altitude: $411.5 \mathrm{~m}$ ) during Kharif 2017, 2018 and 2019. Experimental location is a hot spot designated by AICRP on soybean for aerial blight disease of soybean. Two susceptible varieties i.e. JS 335 and JS 97-52 that also mature around in 100 days were sown in 8 rows plot with keeping 5 meter length and $40 \mathrm{~cm}$ distance. To protect the insect pest i.e. white fly and others at initial stage of crop, the seeds were treated with thiomethoxam 30\%FS@10 ml $/ \mathrm{kg}$ at the time of sowing. The sowing was accomplished between $30^{\text {th }}$ June to $2^{\text {nd }}$ of July in all three years and total three sets of both varieties were sown in different direction in the same the field. Thinning and other practices were followed as per the recommendations except application of fungicides. Plants affected by other disease were roughed out as early as appearance.

\section{Measurement of disease progress}

Progress of aerial blight was recorded from at least twenty five randomly selected plants on every Standard Meteorological Week (SMW) basis from vegetative (V3) to maturity stages (R7). Each selected plants were approximately divided into three positions as bottom, middle and top and from each position two to four leaves were graded. Based on percentage leaf area affected byaerial blight 0-9 ratings were assigned for each infected leaves (Mayee and Datar, 1986, Amrate et al., 2018)

\section{Calculation of per cent disease index and area under disease progress curve}

These above grades (0-9) were then utilized for the calculation of Per cent Disease Index (PDI) by using the following formula given by Wheeler, (1969).

PDI $=\{($ Sum of individual $\mathrm{rating} /$ No. of leaves examined) $\mathrm{x} 11.11\}$

Week wise increased PDI for each variety was also calculated for further analysis of data. By using per cent disease index (PDI) values at different intervals from initiation of disease (July) to the last observation at time of maturity (September), Area under disease progress curve (AUDPC) was calculated as given by Shaner and Finney (1977).
$\operatorname{AUDPC}=\sum_{i=1}^{n}\left[\left(\mathrm{y}_{\mathrm{i}}+\mathrm{y}_{\mathrm{i}+1}\right) / 2\right]\left[\mathrm{t}_{\mathrm{i}+1}-\mathrm{t}_{\mathrm{i}}\right]$

Where, $\mathrm{y}_{\mathrm{i}}=$ PDI at $\mathrm{i}^{\text {th }}$ observation, $\mathrm{t}_{\mathrm{i}}=$ time (days) at $\mathrm{i}^{\text {th }}$ observation, and $\mathrm{n}=$ number of observation.

\section{Sclerotial counting}

It was noticed that small brown sclerotias were formed on the infected as well as adjoining healthy tissues along with progression of RAB. Approximate numbers of sclerotia were only counted on ten infected or blighted trifoliate leaves (including petioles) of randomly selected plants at weekly interval along with the observation of disease progress on the same set of plants. Subsequently, it was averaged for approximate number of sclerotial count for single infected trifoliate leave.

\section{Weather parameters}

Standard meteorological week (SMW) wise weather variable i.e. maximum temperature, minimum temperature, morning and evening humidity and rainfall $(\mathrm{mm})$, sun shine hours and number of rainy days were obtained from the Meteorological Observatory, situated within the campus of university for the period of investigation.

\section{Correlation coefficient and multiple linear regression analysis}

Pearson correlation coefficient (r) was calculated between weekly weather parameters and disease progression (averaged increased PDI and Sclerotial count for JS 335 and JS 97-52) for the period of $33^{\text {rd }}$ (August, 13-19) to $39^{\text {th }}$ (September, 24-30) SMW. It was calculated in two way first, current week weather with disease and second, previous week weather with disease for all three year (pooled). Moreover, $r$ values were also determined to establish relation between increasing crop age and disease severity and sclerotial count.

The similar set of disease progression data (SM week wise) were also subjected for regression analysis to characterized the mathematical relationship between dependent (RAB severity) and independent (weather parameters) variables. Primarily, Akaike's Information Criterion (AIC) and R-squared were worked out by using all variables to identify the best suited meteorological variables for the prediction of RAB severity. Stepwise regression analysis was also performed for the development of multiple linear regression models for prediction of Rhizoctonia aerial blight (RAB) severity under different set of field conditions. The model can be defined as presented below 

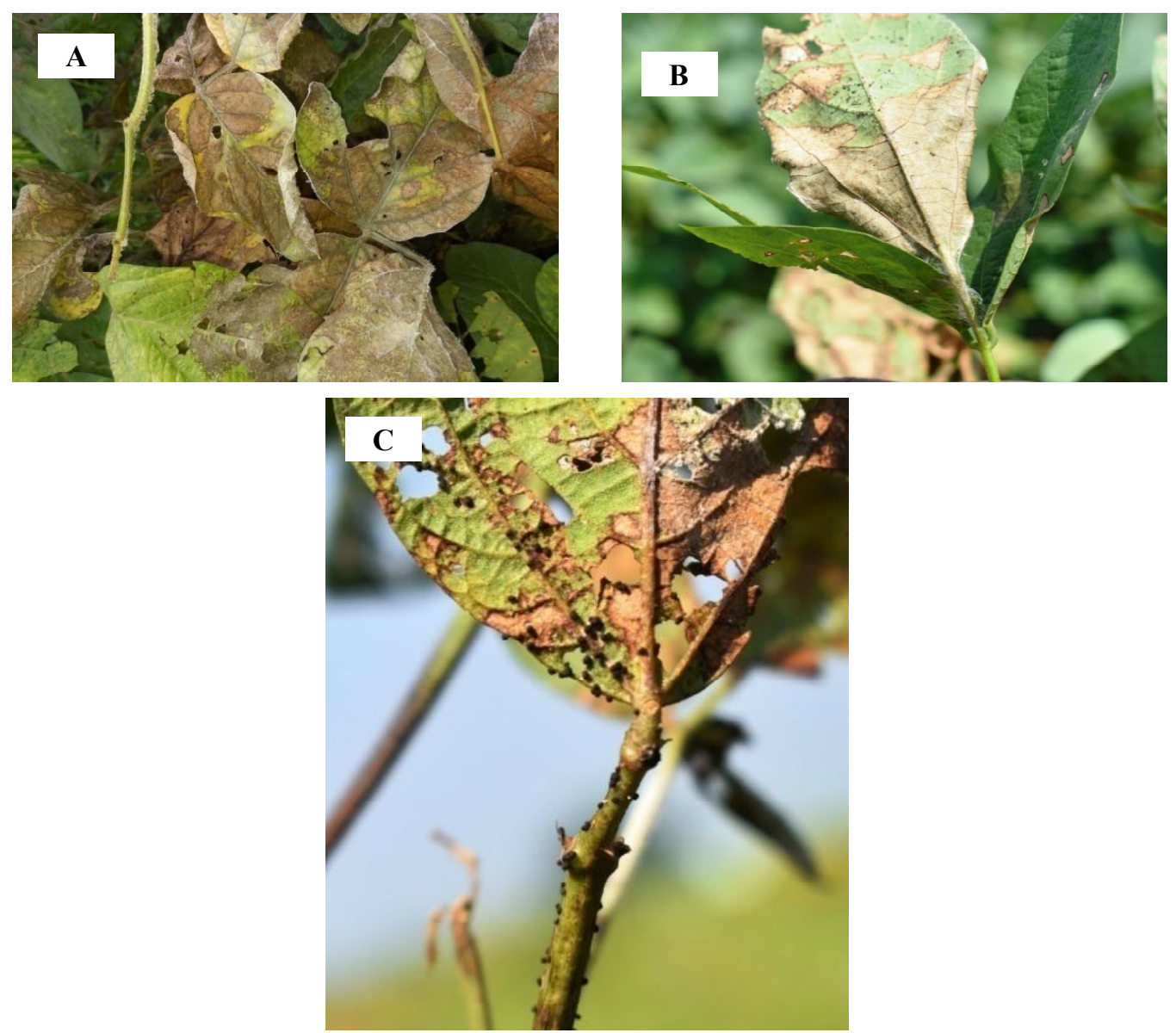

Fig. 1: Close up view of severe progress of rhizoctonia aerial blight (RAB) with dark brown water soaked lesion and presence of aerial mycelium (A), Partial blighting along with web like mycelium and sclerotial formation (B) and, dark brown sclerotial formation of disease affected leave and petioles of soybean $(\mathrm{C})$, respectively.

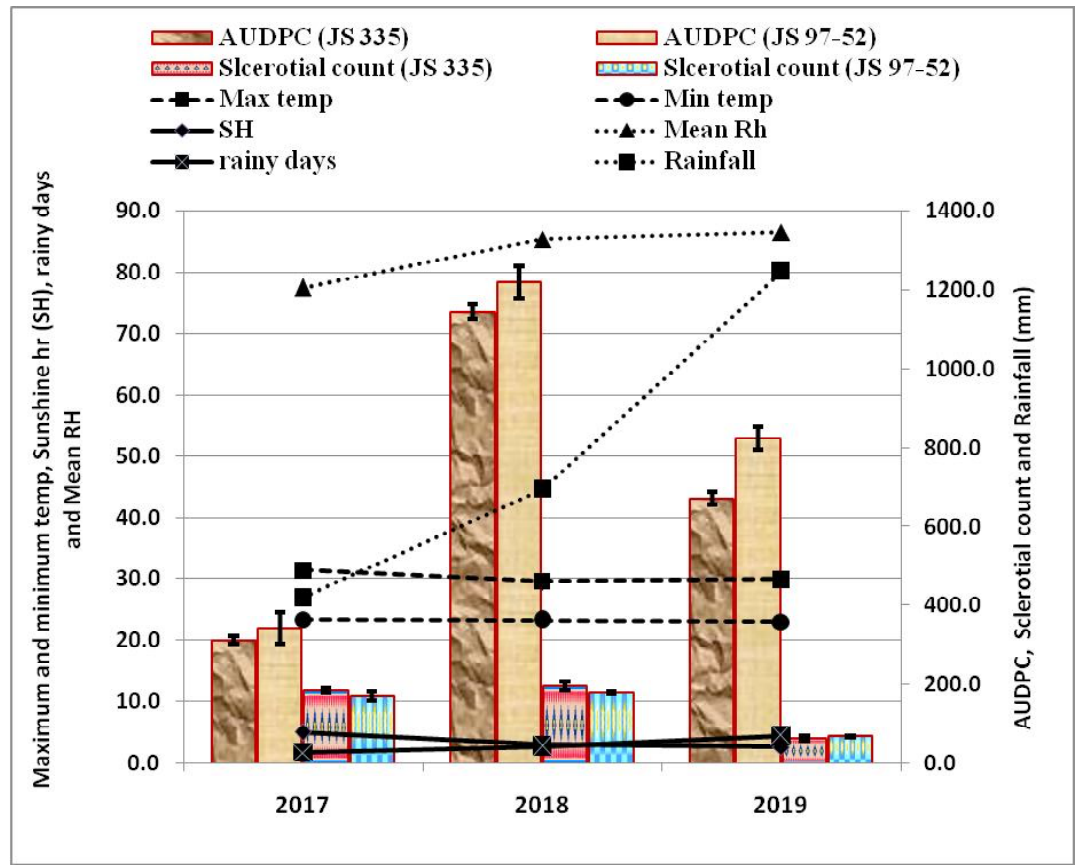

Fig. 2: Season wise fluctuations of AUDPC aerial blight and Sclerotial count on each infected leaf, and average weather variables during 2017, 2018 and 2019. 
Table 1: Seasonal fluctuations of severity of aerial blight and formation of sclerotia on affected leaves

\begin{tabular}{|c|c|c|c|c|c|c|c|c|c|}
\hline \multirow[t]{2}{*}{ Season/Year } & \multicolumn{3}{|c|}{ Per cent disease index } & \multicolumn{3}{|c|}{ AUDPC } & \multicolumn{3}{|c|}{ Sclerotial count } \\
\hline & JS 335 & JS $97-52$ & Mean & JS 335 & JS 97-52 & Mean & JS 335 & JS97-52 & Mean \\
\hline 2017 & 14.4 & 16.7 & 15.56 & 310.3 & 340.4 & 325.4 & 184.7 & 169.7 & 177.2 \\
\hline 2018 & 41.4 & 45.2 & 43.31 & 1145.2 & 1220.8 & 1183.0 & 196.0 & 178.3 & 187.2 \\
\hline 2019 & 30.1 & 34.9 & 32.48 & 671.5 & 824.3 & 747.9 & 62.0 & 67.3 & 64.7 \\
\hline Mean & 28.7 & 32.3 & - & 709.0 & 795.2 & - & 147.6 & 138.4 & - \\
\hline $\operatorname{LSD}(p=0.05)$ & \multicolumn{3}{|c|}{$\begin{array}{l}\mathrm{V}=1.49, \mathrm{~S}=2.36 \\
\mathrm{~V} \times \mathrm{S}=2.59\end{array}$} & \multicolumn{3}{|c|}{$\begin{array}{l}V=48.72, S=57.36 \\
V \times S=84.39\end{array}$} & \multicolumn{3}{|c|}{$\begin{array}{c}\mathrm{V}=13.59, \mathrm{~S}=14.84 \\
\mathrm{~V} \times \mathrm{S}=23.54\end{array}$} \\
\hline
\end{tabular}

$\mathrm{V}=$ Variety, $\mathrm{S}=$ season

Table 2 : Pearson correlation matrix between standard meteorological week wise averaged disease progression (JS 355 and JS 97-52) and weather variables for the year 2017, 2018 and 2019

\begin{tabular}{lllllllll}
\hline $\begin{array}{l}\text { PDI/Sclerotial } \\
\text { count increased }\end{array}$ & $\begin{array}{l}\text { Current/ } \\
\text { previous week }\end{array}$ & Crop age & Max temp & Min temp & $\begin{array}{l}\text { Sunshine } \\
\text { hours (SH) }\end{array}$ & $\begin{array}{l}\text { Cumulative } \\
\text { rainfall }(\mathrm{mm})\end{array}$ & Mean RH & Rainy days \\
\hline PDI & Current & $0.732^{*}$ & -0.056 & 0.112 & -0.089 & -0.295 & 0.185 & -0.085 \\
& previous & 0.593 & -0.174 & -0.167 & 0.005 & -0.286 & 0.259 & 0.313 \\
\multirow{2}{*}{ Sclerotial count } & Current & $0.981^{* *}$ & $0.923^{* *}$ & $-0.883^{* *}$ & $0.896^{* *}$ & $-0.962^{* *}$ & $-0.767^{*}$ & $-0.887^{* *}$ \\
& previous & $0.993^{* *}$ & $0.849^{*}$ & $-0.892^{* *}$ & $0.833^{*}$ & $-0.969^{* *}$ & -0.595 & -0.690 \\
\hline
\end{tabular}

PDI $=$ per cent disease index,${ }^{*}=$ significant at 5 per cent $(\mathrm{p}=0.05),{ }^{* *}=$ highly significant at 1 per cent $(\mathrm{p}=0.01)$,

$$
\mathrm{Y}=\beta_{0}+{ }_{1} \mathrm{X}_{1}+\beta_{2} \mathrm{X}_{2}+\beta_{3} \mathrm{X}_{3}+\ldots \ldots \ldots \beta_{4} \mathrm{X}_{4}+\varepsilon
$$

Where $Y=R A B$ severity (IncreasedPDI), $\beta_{0}=$ Intercept (constant), $\beta_{1}$ to $\beta_{4}=$ regression Coefficient, $\mathrm{X}=$ weather variables i.e. maximum temperature (Max T), Minimum temperature (Min T), mean relative humidity (Mean $\mathrm{RH}$ ), cumulative rainfall in mm (Rainfall), sun shine hours ( $\mathrm{SS} \mathrm{hr}$ ), rainy days etc

\section{Data analysis}

All the requisite data, for correlation coefficient and multiple linear regressions, were analyzed by using SPSS 16.0 statistical software and standard version of Analysis It with Microsoft excel.

\section{RESULTS AND DISCUSSION}

\section{Symptoms and Seasonal fluctuations of disease}

The major characteristic symptoms such as gray to reddish brown irregular water soaked lesions, web of mycelium (aerial hyphae) and small dark brown Sclerotia of fungus were noticed conspicuously on affected foliages of plant (Fig 1). Aerial blight severity in term of percent disease index, AUDPC and total sclerotial count were varied significantly in both varieties i.e. JS 335 and JS 97-52 for all three growing season 2017, 2018 and 2019 (Table 1). The highest averaged per cent disease index (43.31\%), AUDPC (1183.0) and sclerotial count (187.2) were recorded in the season 2018 . The overall weather of 2017 was comparatively dried (less humid) and hot with less rainfall that might be resulted in low severity of aerial blight. Whereas other two years (2018 \& 2019), where in disease severity was higher, were wet with moderate temperature and high rainfall (Fig. 2). Joye (1986) and Yang et al. (1990) also reported formation of aerial mycelium and sclerotia on aerial blight affected parts of plants. Yang et al. (1990) and Wrather et al (2010) also suggested that high rainfall encourages the high severity of the aerial blight in soybean.

\section{Disease progress with crop growth stages}

Incidence of Rhizoctonia aerial blight (RAB) was started in first fortnight of August (35-45 days after sowing)in all three year that coincided with the flowering stage (R1 and R2) of crop (Fig. 3). Thereafter, the disease progress continuously (till the maturity, R7). Whereas sclerotial formation on affected tissue was first noticed after 8-15 days of symptoms appearance and then after it also progressed rapidly with the age of crop. RAB severity was increased sharply between 63-84 days old crop \{full pod (R4) to maturity initiation (R7) stage $\}$. The correlation coefficients were also revealed positive significant relation between 
Table3: Akaike's information criterion (AICc) and R-squared regression analysis to select best suited meteorological variables for development of aerial blight prediction model in the field conditions on JS 335 and JS 97-52

\begin{tabular}{|c|c|c|c|c|c|c|}
\hline Model fit & Max temp & Min temp & Sunshine hours & Rainfall & Mean RH & Rainy days \\
\hline \multicolumn{7}{|c|}{ Current week $(2017,2018 \& 2019)$} \\
\hline AIC & 24.866 & 24.804 & 24.834 & 24.253 & 24.646 & 24.840 \\
\hline AICc & 32.866 & 32.804 & 32.834 & 32.253 & 32.646 & 32.840 \\
\hline RMSE & 1.1017 & 1.0969 & 1.0992 & 1.0545 & 1.0845 & 1.0996 \\
\hline $\mathrm{R}^{2}$ & 0.003 & 0.012 & 0.008 & 0.087 & 0.034 & 0.007 \\
\hline \multicolumn{7}{|c|}{ Previous week $(2017,2018 \& 2019)$} \\
\hline AIC & 24.671 & 24.694 & 24.889 & 24.290 & 24.404 & 24.159 \\
\hline AICc & 32.671 & 32.694 & 32.889 & 32.290 & 32.404 & 32.159 \\
\hline RMSE & 1.0865 & 1.0883 & 1.1035 & 1.0573 & 1.0660 & 1.0475 \\
\hline $\mathrm{R}^{2}$ & 0.031 & 0.028 & 0.000 & 0.082 & 0.067 & 0.099 \\
\hline
\end{tabular}

$\mathrm{AICc}=$ Akaike's Information Criterion corrected, RMSE $=$ Root Mean Square Error

increasing crop age with weekly increased PDI $\left(0.732^{*}\right)$ and weekly increased sclerotial count $\left(0.981^{* *}\right)$, respectively (Table 2). Similar finding was also reported Patel and Bhargava (1998) that aerial blight generally appeared at flowering and severity increases with crop canopy and age.

\section{Correlation of weekly disease progression with weather}

Standard Meteorological (SM) week wise weather parameters and disease severity were varied over the season, and maximum average increased per cent disease index (PDI) and sclerotial count was observed between 35 to 37 and 38 to $39 \mathrm{SMW}$, respectively (Fig 3). Increased PDI was positively and negatively correlated with current week mean RH and maximum temp, respectively (Table 2). In case of previous week weather, number of rainy day (0.313) and Mean $\mathrm{Rh}$ (0.259) had highest positive correlation with severity increase of disease. Sclerotial count was highly significantly positively and negatively correlated with current week maximum temp $\left(0.923^{* *}\right)$ and cumulative rainfall $\left(-0.962^{* *}\right)$, respectively. Whereas similar kind of significant association were also found between sclerotial count and previous week weather.

Based on three year observation on disease progression and correlation coefficient, weekly average maximum temp ranging from 27 to $30^{\circ} \mathrm{C}$ and mean $\mathrm{RH} 80$ to 90 per cent in current week coupled with more rainfall and rainy days in previous week were found to be most conducive field condition for rapid progress of aerial blight in soybean. It was also found that sclerotia formation in affected tissue increases with the increase of maximum temp $\left(>30^{\circ} \mathrm{C}\right)$ and less rainfall. Sikora et al. (2011) also reported that prolonged humidity and warm temperature favored disease progress and which further be limited during an abnormally dry period. As per Mathpal (2016) aerial blight progression negatively correlated with temperature and Relative humidity, and positively with rainfall and sunshine hours under north Indian conditions.

\section{$R A B$ prediction models}

To identify the weather variables, which itself could be most effective for predicting aerial blight severity, Akaike's Information Criterion and other statistics were calculated (Table 3). Based upon lowest corrected Akaike's Information Criterion (AICc) and highest R - squared values, amount of rainfall in current week and number of rainy days in previous week were identified as single largest influencer in determination of aerial blight severity. In various models derived by multiple linear regression (Table 4), a model i.e. $\mathrm{RAB}=-58.8+0.433($ Mean RH) $-0.0498($ Rainfall $)+1.354$ (Min temp), with current week weather, was found to be most significant and accounted 94.6 per variability $\left(\mathrm{R}^{2}=0.946\right)$ of RAB severity with only three variables. However, Coefficient of determination $\left(\mathrm{R}^{2}\right)$ of this model could be increased up to 0.979 , with significance, by adding one more variable i.e. sun shine hours. Another prediction model $\{\mathrm{RAB}=2.818+$ 1.263 (rainy days) - 0.02809 (Rainfall), $\left.\mathrm{R}^{2}=0.717\right\}$, with previous week weather variable, was also found good and both two i.e. rainfall and rainy days played significant role. By using these equations, expected values of aerial blight were also calculated for each one best for current and previous week weather equations and this also showed very low residual (Fig 4: A,B). Hence, these equations could be utilized for the prediction of aerial blight severity in soybean. Kumar and Dubey (2002) also found that weather variables 
Table 4: Stepwise multiple linear regression equations for the prediction of Rhizoctonia aerial blight (RAB) severity on independentSMW weather variableson JS 335 and JS 97-52.

\begin{tabular}{lllll}
\hline Multiple regression equations/models & $\mathrm{R}^{2}$ & Adjusted R & F calculated $^{2}$-value** \\
\hline
\end{tabular}
1. Equation $\mathrm{RAB}=-32.7+0.483(\mathrm{Mean} \mathrm{RH})-0.0377$ (Rainfall)
$0.742 \quad 0.613$
5.75
0.066
$p$ value $* \quad \beta 0=0.050, \beta 1=0.033$ and $\beta 2=0.029$

2. Equation $\mathrm{RAB}=-58.8+0.433($ Mean $\mathrm{RH})-0.0498$ (Rainfall)

$+1.354(\mathrm{Min} \mathrm{T})$

$\begin{array}{llll}0.946 & 0.892 & 17.47 & 0.021\end{array}$

$\mathrm{p}$ value* $\beta 0=0.009, \beta 1=0.013, \beta 2=0.005$ and $\beta 3=0.043$,

3. Equation $\mathrm{RAB}=-82.97+1.853($ Min $\mathrm{T})+0.5611($ Mean RH$)-\quad 0.979 \quad 0.936 \quad 22.92 \quad 0.042$

0.04889 (Rainfall) $+0.4842(\mathrm{Ss} \mathrm{Hr})$

$\mathrm{p}$ value* $\beta 0=0.0343, \beta 1=0.0479, \beta 2=0.0282$

and $\beta 3=0.0120$ and $\beta 4=0.2218$

Previous week $(2017,2018 \& 2019)$

$\begin{array}{lllll}\text { 1. Equation } & \mathrm{RAB}=2.818+1.263 \text { (Rainy days) }-0.02809 \text { (Rainfall) } & 0.717 & 0.575 & 5.06 \\ \text { p value* } \quad \beta 0=0.047, \beta 1=0.040 \text { and } \beta 2=0.041 & & & 0.0802\end{array}$

2. Equation $\mathrm{RAB}=-22.67+1.375$ (Rainy days) -0.0388 (Rainfall) $\quad 0.800 \quad 0.601 \quad 4.01 \quad 0.1419$

\section{$+1.123(\operatorname{Min} \mathrm{T})$}

p-value $* \quad \beta 0=0.3923, \beta 1=0.0469$ and $\beta 2=0.0613$ and $\beta 3=0.3436$

Ave-Average, T-temperature,SsHr - Sunshine hours, $\beta 0$ (Intercept), $\beta 1, \beta 2, \beta 3$, and $\beta 4$ (regression coefficient), $\mathrm{p}$ value* - ${ }^{2}$ significance level(t statistics), $\mathrm{p}$ value** - model significance

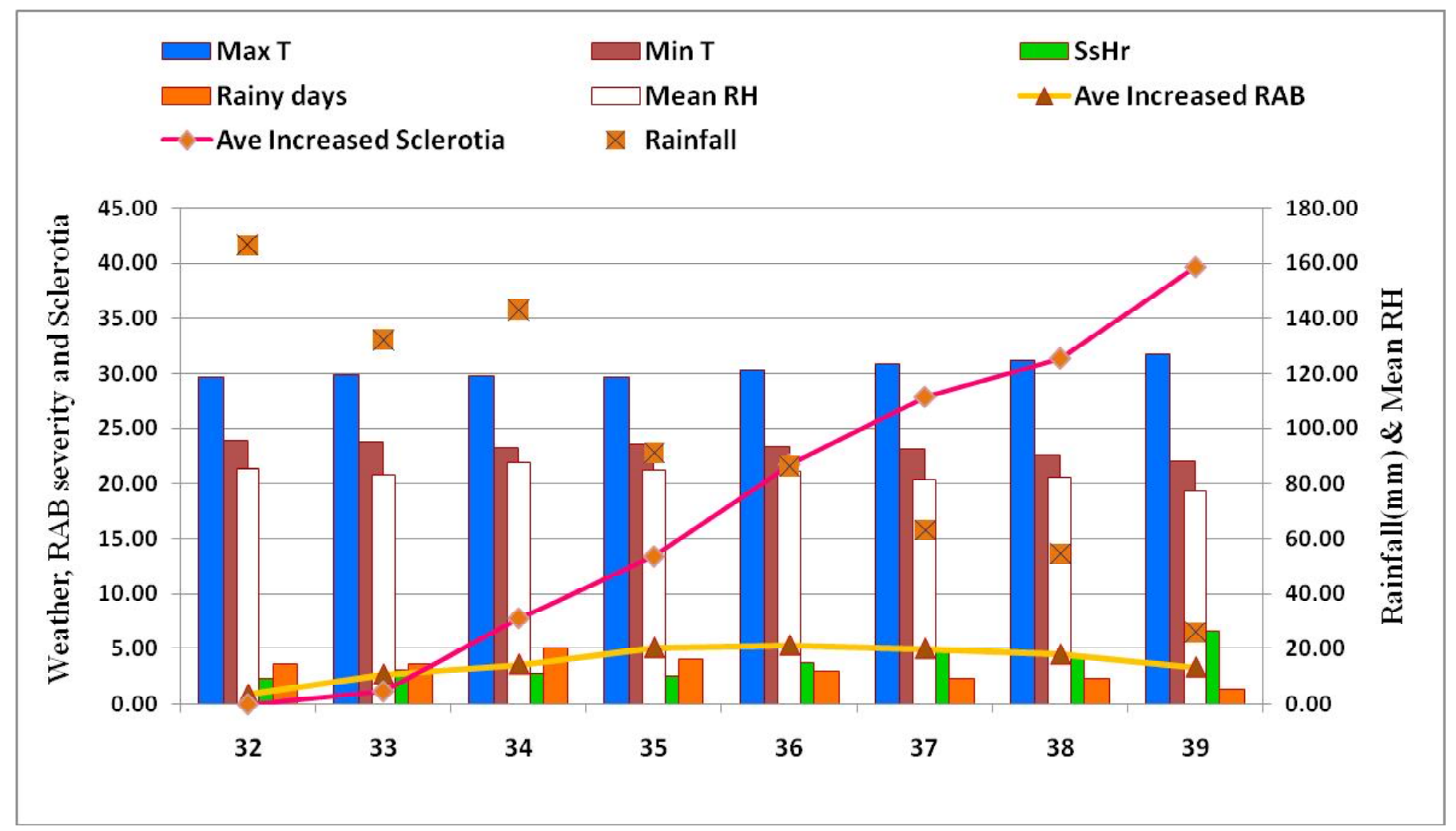

Fig.3: Standard meteorological week wise weather parameters and corresponding increase of rhizoctonia aerial blight (RAB) and sclerotial count on each infected leaves for the year 2017, 2018 and 2019 (pooled). 

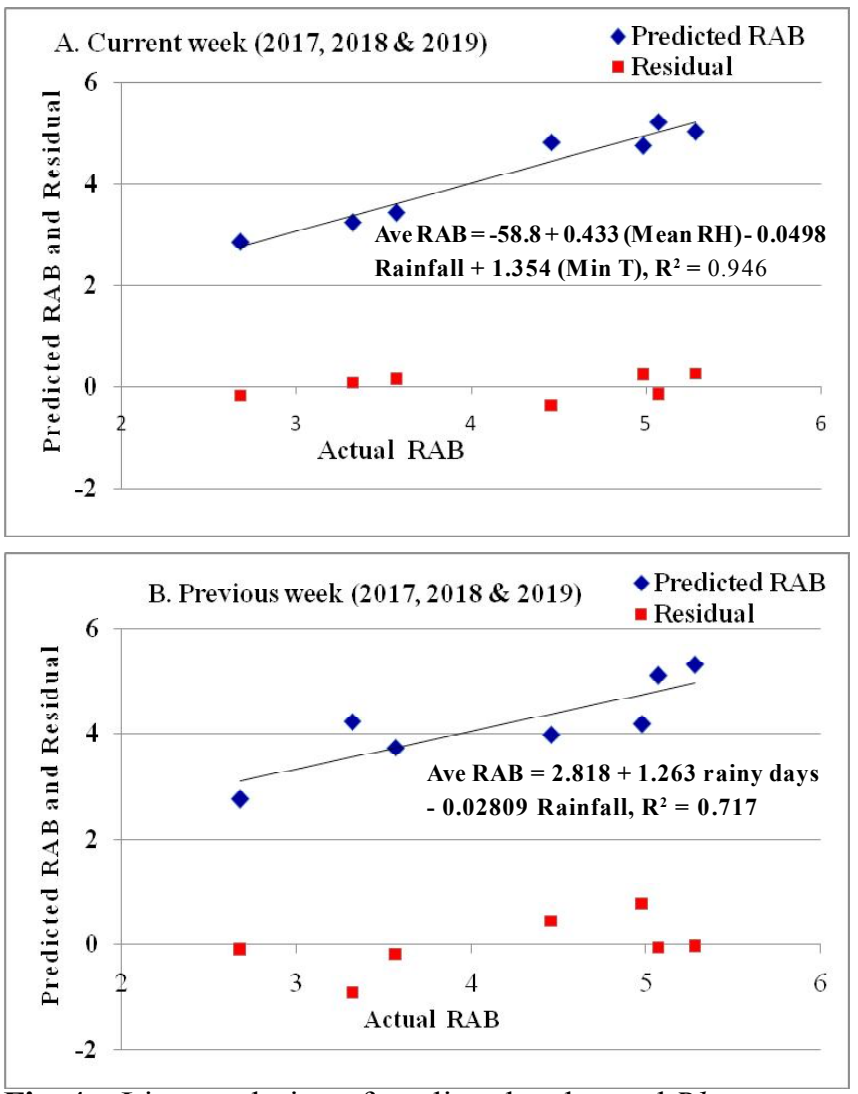

Fig. 4: Linear relation of predicted anda ctual Rhizoctonia Aerial Blight (RAB) on current week three weather variables (A) and previous week two weather variables (B), respectively.

accounted more than 80 per cent variation in web blight of winged bean caused by $R$. solani. Surbhi and Singh (2020) also worked out prediction equation and reported that weather variables determined $65-70$ percent ( $\mathrm{R}^{2}$ values) variation in aerial blight severity of soybean in north Indian conditions.

\section{CONCLUSION}

The study concluded that aerial blight infects the crop between flowerings to maturity in both variety i.e. JS 335 and JS 97-52, and severity increased with increasing crop age. Weather variables i.e. Mean Rh, Rainfall and Maximum temperature of previous as well as current week played greater role in diseases progress and also influenced sclerotial formation on affected leaves. The weather based regression models derived in this study would be helpful in prediction of aerial blight severity and thereby, need based spraying or other practices may be adopted to avoid severe yield losses due to disease.

\section{ACKNOWLEDGEMENTS}

The author expresses his sincere thanks to In-charge,
AICRP on Soybean, Head department of Plant Breeding \& Genetics and other staffs of the project for providing financial as well as other supports. We are also thankful to In-charge AICRP on Agro meteorology at university for furnishing weather data for the cropping season.

\section{REFERENCES}

Amrate, P.K., Pancheshwar D.K. and Shrivastava, M.K. (2018). Evaluation of soybean germplasm against charcoal rot, aerial blight and yellow mosaic virus disease in Madhya Pradesh. Pl. Dis. Res.,33 (2): 185-190

Amrate, P.K., Shrivastava, M.K. and Singh, G. (2020). Screening of Genotypes to Identify the Resistance Source against Major Diseases of Soybean under High Disease Pressure Conditions. Int.J.Curr.Microbiol.App.Sci.,9 (5): 17391745.

Anonymous. (2020). The Soybean Processors Association of India (SOPA) report http://www.sopa.org/statistics/ world-soybean-production/

Joye, G.F. (1986). Management of Rhizoctonia aerial blight of soybean and biology of sclerotia of Rhizoctoniasolani Kühn. Ph. D. thesis. Louisiana State University, Baton Rouge. $91 \mathrm{pp}$.

Joye, G.F., Berggren, G.T. and Berner, D.K. (1990). Effects of row spacing and within-row plant population on Rhizoctonia aerial blight of soybean and soybean yield. Plant Dis., 74: 158-160.

Kumar, M. and Dubey, S.C. (2002). Relationship of disease intensity with weather and management of web blight of winged bean. Indian Phytopath., 55(2):152-157.

Manian, S. and Manibhushanrao, K. (1990). Influence of some factors on the survival of Rhizoctoniasolaniin soil. Tropical Agric., 67(3): 207-208.

Mathpal, M. (2016). Epidemiology and management of Rhizoctonia aerial blight of soybean (Glycine max L. Merrill).Ph.D.Thesis, G.B.Pant Universityof Agriculture and Technology, Pantnagar, p 221.

Mathpal, M. and Singh, K.P, (2017).Prevalence and severity of rhizoctonia aerial blight of soybean in Uttarakhand. Indian J. Eco., 44(2):417-419.

Mayee, C.D. and Datar, V.V. (1986). Phytopathometry technical bulletin-1 (Specialbulletin-3). Marathwada Agricultural University, Parbhani, pp 34-37.

Mohanty, M., Sinha, N.K., McDermid, S.P., Chaudhary, R.S., Reddy, K.S., Hati, K.M., Somasundaram, J., Lenka, S., 
Patidar, R.K., Prabhakar, M., Cherukumalli, S.R., Patra, A.K. and Sinha, N.K. (2017). Climate change impacts vis-a-vis productivity of soybean in vertisol of Madhya Pradesh. J. Agrometeorol., 19 (1): 10-16.

Naito, S., Mochida, H., Nakajima, T. and Ohto, Y. (1995). Infection with basidiospores of Thanatephoruscucumeris (AG-2-3 of Rhizoctoniasolani) and development of soybean foliar blight lesions. Ann. phytopath. Soc. Japan,61: 362368.

Patel, B.L. and Bhargava, P.K. (1998).Aerial blight of soybean (Glycine max.) caused by Rhizoctoniasolani. IndianJ. Agric. Sci., 68(5): 277- 278.

Prasad,Y.G., Gayathri, M., Prabhakar, M., Jeyakumar, P., Vennila, S., Subba Rao,A.V.M, Bhaskar Rao, I., Rao, K.V., Rao, R., and Rao, V.U.M. (2013). Population dynamics of Spodoptera litura outbreak on soybean vis-a-vis rainfall events. J. Agrometeorol., 15(1): 37-40.

Shaner, G. and Finney, R.E. (1977). The effect of nitrogen fertilization on the expression of slow-mildewing resistance in Knox wheat. Phytopathol., 67:1051-1056.

Sikora, E.J., Murphy, J.F., Lawrence, K.S., and Mullen, J.M. (2011). Survey of fungal, nematode and viral diseases of soybean in Alabama. Online. Plant Health Progress doi:10.1094/PHP-2011-1227-01-RS.
Sinclair, J.B. (1984). Compendium of Soybean disease. 2nd ed. by American Phytopathology Society, USA.

Surbhi, K. and Singh, K. P. (2020). Influence of weather factors on severity of aerial blight of soybean. Indian Phytopath.73: 493-497.

Verma, H.S. and Thapliyal, P.N. (1976). Rhizoctonia aerial blight of soybean. Indian Phytopath.,29(4): 389-391.

Wan, G. K., Sung, K.H. and Seong, S.H. (2005). Occurrence of web blight in soybean caused by Rhizoctoniasolani AG1(IA) in Korea. Plant Pathol J., 21(4):406-408

Wheeler, B.E.J. (1969). An Introduction to Plant Diseases. John Wiley and Sons Ltd., London. 301pp.

Williamson, M.R., Rothrock, C.S. and Muellar, J.D. (2006). First report of foliar blight of soybean in South Carolina. Plant Health Progress, 3:1-3.

Wrather,A., Shannon, G., Balardin, R., Carregal, L., Escobar, R., Gupta, G. K., Ma, Z., Morel, W., Ploper, D., and Tenuta, A. (2010). Effect of diseases on soybean yield in the top eight producing countries in 2006. Online. Plant Health Progress doi:10.1094/PHP-2010- 0125-01-RS.

Yang, X.B., Snow, J.P. and Berggren, G.T. (1990) Analysis of epidemics of Rhizoctonia aerial blight of soybean in Louisiana. Phytopathology 80:386-392. 